\title{
A Study of Sasanian Silver Coins Employing the XRF Technique
}

\author{
Bita Sodaei $^{\mathrm{a}}$, Parasto Masjedi Khak ${ }^{\mathrm{b}^{*}}$, Mostafa Khazaie ${ }^{\mathrm{b}}$ \\ ${ }^{a}$ Department of Archaeology, Islamic Azad University, Varamin, Iran \\ ${ }^{b}$ Department of Archaeology, Tarbiat Modares University, Teheran, Iran
}

\section{ARTICLE INFO}

\section{Article history:}

Received: 2. January 2013

Accepted: 2. December 2013

Key words:
Sasanain
coins
silver
mines
XRF

\begin{abstract}
$A B S T R A C T$
The percentage composition of metallic silver coins can be used to analyse and explain the locations and identification of coin mines. Furthermore, it provides certain information about the economic and political conditions of the era under study. Commercial activity and population growth increased the demand for silver, forcing the Sasanians to look for new sources for this metal. The aim of this work is to study the chemical composition of these Sasanian coins in order to find possible connections between the mines used for extraction of silver and the actual silver coins minted at the time. Using the wavelength dispersive $\mathrm{X}$-ray fluorescence (XRF) technique, the metallic elements $\mathrm{Fe}, \mathrm{Cu}, \mathrm{Zn}, \mathrm{Ag}$, $\mathrm{Au}$ and $\mathrm{Pb}$ were traced. The results indicate that Sasanian kings used one type of mines for their coins.
\end{abstract}

\section{Introduction}

Coins play an important role in our cultural heritage and usually have a high artistic and cultural value. In connection with iconography, the archaeological issues concern the question of dating, provenance, technology of production and authenticity.

From the historical point of view, the Sassanid Empire or Sasanian Dynasty was the name used for the third Iranian dynasty and the second Empire. The Sasanid Empire was founded by Ardashir I in 224 A.D. after the fall of the Arsacid Empire. The Sasanid Empire was one of the most remarkable empires and civilizations of the First Millennium AD. One of the two great powers of late antiquity, the Sasanian domain eventually encompassed not only modern-day Iran and Iraq, but also controlled or influenced the greater part of Central Asia, Afghanistan, Turkmenistan, Uzbekistan, the Caucasus, Armenia, Georgia and the Near East. This geographically diverse empire brought together a striking array of tonicities and religious practices. Throughout its existence, the Sasanid Empire was an absolute monarchy. This came to an end when the last Sasanid King Yazdegerd III (632-652 A.D.) lost a fourteen years struggle to drive out the expanding Islamic Empires (Frye 2005).

*Corresponding author. E-mail: parastomasjedi@yahoo.com
This article making use of the XRF technique to study ancient coins is one of the prevailing methods for finding the chemical composition of ancient metals (Link et al. 2004). The investigation techniques include wavelength dispersive X-ray fluorescence analysis (WDXEF) which can be applied non-destructively without sampling, although XRF is limited in the sample size. Moreover, XRF has a poor sensitivity for trace elements and for elements with an atomic number lower than $11(\mathrm{Na})$. The detection limits of XRF are approximately 0.1 wt. This information can be used to determine the economic conditions and possible sources of metals. Among the various spectroscopy techniques, XRF is a particularly useful one and non-destructive (Guera 1995). Using XRF as an analytical technique, we have focused on metals once used in the Sasanian period in Iran.

\section{Background for the research}

Bacharch's work on the chemical compositions of Sasanian silver coins ranks among the finest research carried out on Sasanian numismatics (Bacharach, Gordus 1972). In terms of foreign scholars, Hughes (Hughes, Hall 1979) not only has worked on Sasanian silver metals but has also compared them with Roman silver metals. The cupellation which is applied for exploration of Galena after oxidation of $\mathrm{Pb}$ and $\mathrm{Zn}$, may 
lead to obtaining Ag. Since Au has not been separated from mines, its amount consequently remains the same with coins. This phenomenon has been reported by both Meyers and Gordus (Meyers 2003; Gordus 1967). Gold has been used as an indication of mines, however. Gordus has additionally used the pt group for the same purpose as well. However, the problem is when the $\mathrm{Au}$ is reeled by other $\mathrm{Ag}$, of other mines the confusion arises to find the mines of $\mathrm{Au}$ which has been explored due to add $\mathrm{Au}$ when added in remolding process they shows high percentage of $\mathrm{Au}$ and it confuse the recognizing mines of exploration. In another research Kallithrakas-Kontos and his colleagues (KallithrakasKontos, Katsanos, Touratsoglou 2000) which has worked on the Alexander silver coins, has showed Bi possibly may be used as the indication for mines (Kallithrakas-Kontos, Katsanos, Touratsoglou 2000). The same method has been applied by Guerra for Au mines and coins (Guerra 1998; 2004; 2008). Hajivaliei and his colleagues were the first Iranian scholars to study Sasanian silver coins with the PIXE technique (Hajivaliei et al. 2008). In connection with this study, we tried to find the connection between silver metals which have been used for issuing the coins and the source of metal being used for the mints during the Sasanian period.

\section{Materials and Methods}

The techniques of investigation include wavelength dispersive X-ray fluorescence analysis (WDXRF) which can be applied non-destructively without sampling, although
XRF is limited in the sample size. Moreover, XRF has a poor sensitivity for trace elements and for elements with an atomic number lower than $11(\mathrm{Na})$. The detection limits of $\mathrm{XRF}$ are approximately $0.1 \mathrm{wt} . \%$, depending on the atomic number and the matrix composition. The detection limits of XRF depend greatly upon the sample, the elements under consideration, the experimental conditions and the detection range (Liritzis, Zacharias 2010). Using this analytical technique and being aware of all the difficulties, we have focused our work on the provenance mines that were used in the Sasanian period in Iran.

\subsection{Experimental setup}

The X-ray fluorescence method (XRF) is undoubtedly the most common technique employed for non-destructive analysis of silver coins. This technique provides rapid, nondestructive, multi-element determination of the composition of an alloy (Hughes, Hall 1979). Since our method is based on an application of non-destructive techniques, XRF was used for the analysis of the silver metallic pieces. The instrument applied for this study was produced by Philips Company, model PW 2404 and its detection limit is \pm 1 ppm. The Philips PW 2404 XRF instrument is designed with an inverted geometry so that the sample is irradiated in Table 1. The loaded quartz filter is placed into a stainless steel sample holder with a $27 \mathrm{~mm}$ opening, loaded side down and secured with an aluminum ring. Each filter is subjected to a full scan to identify all the emitted elements. The resulting fluorescence is focused by a $150 \mu \mathrm{m}$ beam collimator, resolved by a lithium fluoride (LiF) 220 crystal, and detected

Table 1. Percentage of current elements in Sasanian coins by XRF.

\begin{tabular}{|c|c|c|c|c|c|c|c|c|c|c|c|}
\hline $\begin{array}{l}\text { Coin } \\
\text { No. }\end{array}$ & King name & $\begin{array}{c}\text { Regnal } \\
\text { year }\end{array}$ & Mint house & $\begin{array}{c}\text { Unit } \\
\text { weight }\end{array}$ & $\begin{array}{l}\text { Weight } \\
\text { (gram) }\end{array}$ & $\mathbf{F e}$ & $\mathrm{Cu}$ & Ag & $\mathbf{A u}$ & $\mathbf{P b}$ & $\mathbf{A u} / \mathbf{A g}$ \\
\hline 1 & Piruz & $459-84$ & Istakhr & Drachma & 4.1 & 0.0 & $2.7 \pm 0.2$ & $96.1 \pm 4.8$ & $0.7 \pm 0.1$ & 0.0 & 0.007 \\
\hline 2 & Piruz & $459-84$ & Ardeshirkhoreh & Drachma & 3.8 & $2.4 \pm 0.2$ & $1.5 \pm 0.1$ & $94.1 \pm 4.7$ & $1.2 \pm 0.1$ & 0.0 & 0.013 \\
\hline 3 & Belash & $484-8$ & Ardeshirkhoreh & Drachma & 4.1 & $7.8 \pm 0.7$ & $1.4 \pm 0.1$ & $89.1 \pm 4.4$ & $0.8 \pm 0.1$ & 0.0 & 0.009 \\
\hline 4 & Kavad & $488-96$ & Istakhr & Drachma & 4.0 & $0.3 \pm 0.0$ & $1.0 \pm 0.1$ & $96.3 \pm 4.8$ & $0.9 \pm 0.1$ & 0.0 & 0.009 \\
\hline 5 & Kavad & $488-96$ & Ardeshirkhoreh & Drachma & 3.6 & $0.3 \pm 0.0$ & $3.5 \pm 0.3$ & $94.3 \pm 4.7$ & $0.9 \pm 0.1$ & 0.0 & 0.009 \\
\hline 6 & Kavad & $488-96$ & Istakhr & Drachma & 4.0 & 0.0 & $2.5 \pm 0.2$ & $95.1 \pm 4.8$ & $0.9 \pm 0.1$ & 0.0 & 0.009 \\
\hline 7 & Kavad & $488-96$ & Darabgird & Drachma & 4.1 & $0.3 \pm 0.0$ & $1.4 \pm 0.1$ & $91.6 \pm 4.6$ & $0.9 \pm 0.1$ & 0.0 & 0.010 \\
\hline 8 & Kavad & $488-96$ & Darabgird & Drachma & 4.0 & $1.0 \pm 0.1$ & $5.0 \pm 0.5$ & $97.2 \pm 4.6$ & $0.3 \pm 0.0$ & 0.0 & 0.003 \\
\hline 9 & Kavad & $488-96$ & Ardeshirkhoreh & Drachma & 4.0 & $0.5 \pm 0.0$ & $3.8 \pm 0.3$ & $94.7 \pm 4.7$ & $1.0 \pm 0.1$ & 0.0 & 0.010 \\
\hline 10 & Xusro I & $531-79$ & Ramhormuz & Drachma & 4.0 & $0.7 \pm 0.1$ & $3.7 \pm 0.3$ & $97.4 \pm 4.7$ & $0.8 \pm 0.1$ & 0.0 & 0.008 \\
\hline 11 & Xusro I & $531-79$ & Istakhr & Drachma & 3.4 & 0.0 & $2.8 \pm 0.3$ & $96.3 \pm 4.8$ & $0.9 \pm 0.1$ & 0.0 & 0.009 \\
\hline 12 & Xusro I & $531-79$ & Bishapur & Drachma & 3.5 & 0.0 & $10.9 \pm 1.0$ & $88.3 \pm 4.4$ & $0.8 \pm 0.1$ & 0.0 & 0.009 \\
\hline 13 & Hormuz IV & 579-90 & Bishapur & Drachma & 4.1 & $1.4 \pm 0.1$ & $0.8 \pm 0.1$ & $96.2 \pm 4.8$ & $0.8 \pm 0.1$ & $0.8 \pm 0.1$ & 0.008 \\
\hline 14 & Xusro II & 590 & Istakhr & Drachma & 4.1 & 0.0 & $6.3 \pm 0.6$ & $92.1 \pm 4.6$ & $0.7 \pm 0.1$ & $0.8 \pm 0.1$ & 0.008 \\
\hline 15 & Xusro II & 590 & Ecbatana & Drachma & 4.0 & 0.0 & $0.9 \pm 0.1$ & $98.1 \pm 4.9$ & $1.0 \pm 0.1$ & 0.0 & 0.010 \\
\hline 16 & Xusro II & 590 & Ardeshirkhore & Drachma & 4.1 & $1.3 \pm 0.1$ & $2.3 \pm 0.2$ & $95.7 \pm 4.8$ & $0.8 \pm 0.1$ & 0.0 & 0.008 \\
\hline 17 & Xusro II & 590 & Sistan & Drachma & 4.1 & 0.0 & $2.0 \pm 0.2$ & $97.0 \pm 4.8$ & $1.0 \pm 0.1$ & 0.0 & 0.010 \\
\hline 18 & Xusro II & 590 & Sistan & Drachma & 4.0 & 0.0 & $3.3 \pm 0.3$ & $95.6 \pm 4.8$ & $1.1 \pm 0.1$ & 0.0 & 0.011 \\
\hline 19 & Kavad II & 629 & Ecbatana & Drachma & 4.1 & 0.0 & $2.1 \pm 0.2$ & $97.1 \pm 4.8$ & $0.7 \pm 0.1$ & 0.0 & 0.007 \\
\hline 20 & Ardeshir III & $628-9$ & Istakhr & Drachma & 4.2 & $0.2 \pm 0.0$ & $1.4 \pm 0.1$ & $97.5 \pm 4.5$ & $0.9 \pm 0.1$ & 0.0 & 0.009 \\
\hline 21 & Ardeshir III & $628-9$ & Bishapur & Drachma & 4.1 & 0.0 & $2.1 \pm 0.2$ & $97.0 \pm 4.8$ & $0.9 \pm 0.1$ & 0.0 & 0.009 \\
\hline 22 & Yazdgird III & $632-51$ & Sistan & Drachma & 4.0 & $0.3 \pm 0.0$ & $6.4 \pm 0.6$ & $91.6 \pm 4.6$ & $0.8 \pm 0.1$ & $0.9 \pm 0.1$ & 0.009 \\
\hline
\end{tabular}


Figure 1. Sasanian silver coins and the concentration of $\mathrm{Au} / \mathrm{Ag} \mathrm{Vs} . \mathrm{Cu} \%$ with the WDXRF technique.

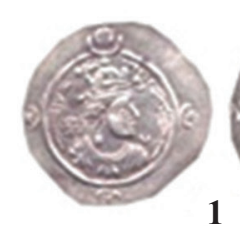

1

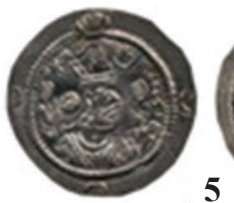

5

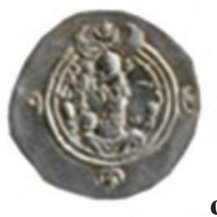

9

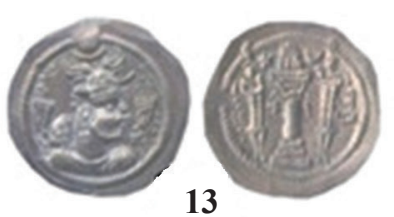

13

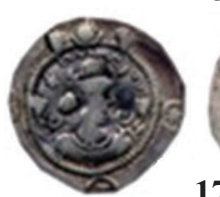

17
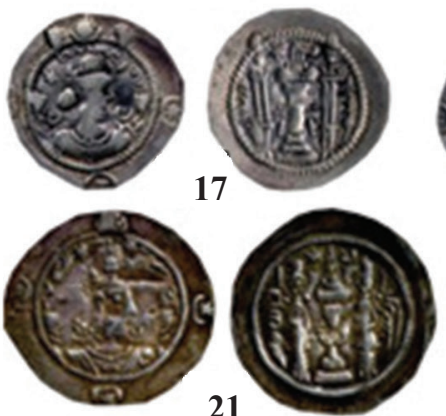

21
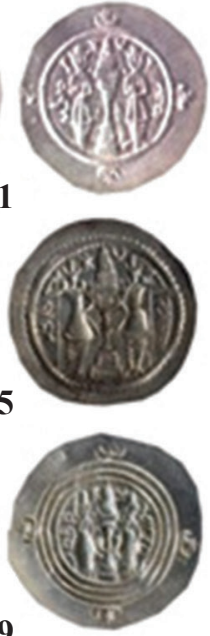
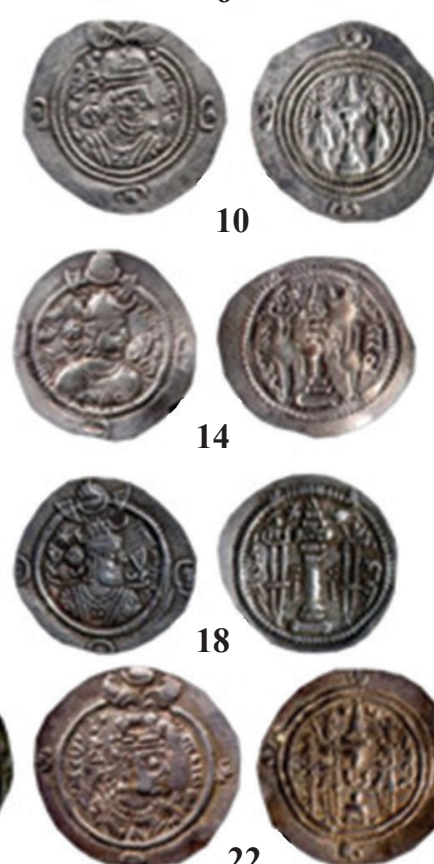

10

2
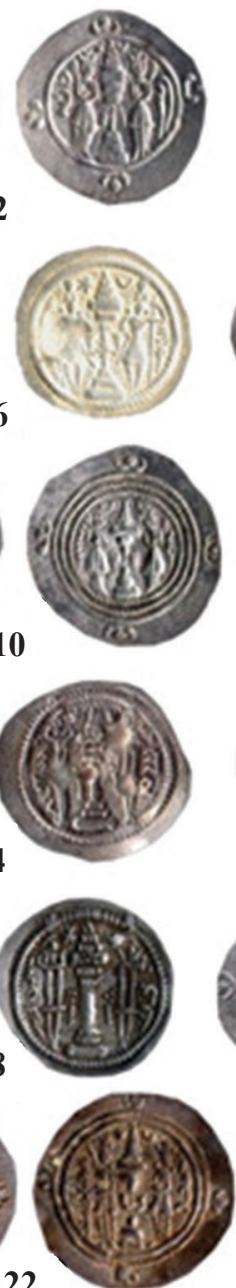

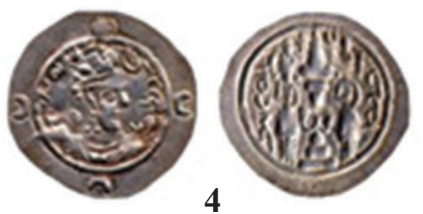

3
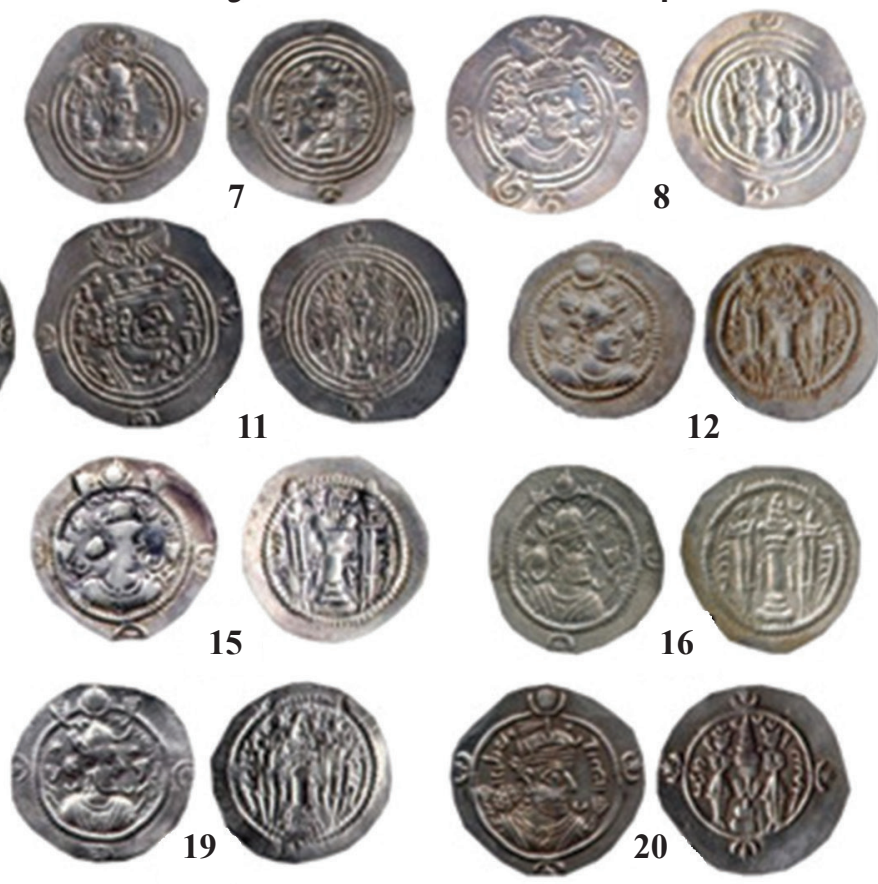

Figure 2. Sasanian silver coins and the concentration of $\mathrm{Au} / \mathrm{Ag}$ Vs. $\mathrm{Cu} \%$ with the WDXRF technique: 1 - Ardeshir III (Istakhr); 2 - Ardeshir III (Bishapur); 3 - Belash (Ardeshirkhoreh); 4 - Xusro I (Istakhr); 5 - Xusro I (Bishapur); 6 - Xusro I (Ramhormuz); 7 - Xusro II (Ardeshirkhoreh); 8 - Xusro II (Istakhr); 9 - Xusro II (Ecbatana); 10 - Xusro II (Sistan); 11 - Xusro II (Sistan); 12 - Piruz (Ardeshirkhoreh); 13 - Piruz (Istakhr); 14 - Kavad I (Ardeshirkhoreh); 15 - Kavad I (Ardeshirkhoreh); 16 - Kavad I (Istakhr); 17 - Kavad I (Istakhr); 18 - Kavad I (Darabgird); 19 - Kavad I (Darabgird); 20 - Kavad II (Ecbatana); 21 - Hormuz IV (Bishapur); 22 - Yazdgird III (Sistan). 
by a flow counter. The analysis of each filter requires less than 6 minutes. UniQuant ${ }^{\mathbb{B}} 4$ was set up at the time of installation to calculate the data collected from the Philips instrument. The analysis of the sample is reported in percentages by weight and the estimated error is provided. The uncertainties are not only statistical, but also originate from the roughness of the coin surface and from the chemical corrosion and/or wearing of the objects, altering the accuracy of the results. The selected Sasanian coins have been cleaned and sent to the XRF Lab at Tarbiat Modares University for analysis.

\subsection{Selection of Samples}

The selected Sasanian silver coins were found in archaeological excavations. After selection, they were classified with their weights indicating that all of them were Drachms. The Sasanian coins belonged to kings who governed 459-651 A.D. These coins are from different mints (Istakhr, Ardeshirkhoreh, Darabgird, Ramhormuz, Bishapur, Ecbatana and Sistan). Nearly all the coins were cleaned after registration in the museum cabinet. They were kept in 3\%-5\% acid formic solution for several minutes and scrubbed with a toothbrush and finally cleaned with alcohol cotton.

\section{Results and Discussion}

The metallic elements $\mathrm{Fe}, \mathrm{Cu}, \mathrm{Zn}, \mathrm{Ag}, \mathrm{Au}$, and $\mathrm{Pb}$ were observed and studied. The ratio of $\mathrm{Ag}$ with respect to $\mathrm{Au}$ reveals several sources of $\mathrm{Ag}$ which have been used for exploration and issuing coins in the Sasanian mint. The presence of $\mathrm{Cu}$ is not only for the shape of the coins but is also used for mine detection. At present approximately half of the silver metals are produced from lead ores, whereas in antiquity this was even higher (Hughes, Hall 1979). Table 1 indicates that only cerussite $\left(\mathrm{PbCo}_{3}\right)$,) mines have been explored for extraction of silver in the mints in the Sasanian Period (Table 1). This means all the Sasanian silver coins which had been minted in Istakhr, Ardeshirkhoreh, Darabgerd, Ramhormuz, Bishapur, Ecbatan and Sistan, had been extracted from cerussite mines. According to Meyers, if the silver was produced from cerussite, the gold content consequently varied from approximately 0.2 to $1.5 \%$, which is valid for our case. Furthermore, it can be stated that $\mathrm{Au}$ is a trace element (Meyers 2003). The comparison of the Au/ $\mathrm{Ag}$ ratio with the $\mathrm{Cu}$ content of the coins indicates (Figure 1) that two mines of the cerussite type were explored for issuing coins, one mine for Piroz, Belash, Xusro I, Hormuz IV, XusroII, Kavad II, Ardeshir III and Yazdegird III coins, whose $\mathrm{Au} / \mathrm{Ag}$ ratio ranges from 0.005 to 0.01 and another one for Piroz and Kavad coins with $\mathrm{Au} / \mathrm{Ag}$ ratios from 0.01 to 0.015 coins, No 2 and 8 are different from the other ones.

$\mathrm{Cu}$ is of course not dissolved in the cupellation process and remains as a base metal in the Ag (Hughes, Hall 1979). The amount of more than $1 \%$ is used, however, as the hardness and retained standard in silver metals. Coins with the numbers 13 and 15 with less $\mathrm{Cu}$, are indicative of the prosperous economic condition during the Hormuz IV and Xusro II periods. The presence Fe may be attributed to the surface contaminations (Kantarelou et al. 2011, Flament, Marchetti 2004). The study of the Saasnian silver coins shows a strong negative correlation between $\mathrm{Ag}$ and $\mathrm{Cu}$, the more the Ag content, the less will be that of $\mathrm{Cu}$. Moreover, negative correlation between $\mathrm{Ag}$ and $\mathrm{Pb}$ can be also seen. The obverse and reverse of the Sasanian coins are provided in Figure 2.

\section{Conclusions}

Based on the above-mentioned results and historical evidence, considering the absence of $\mathrm{S}$ in the analyzed Sasanian coins, it can be concluded that extractions of silver were not from Sulfide ores like galena $(\mathrm{PbS})$. In these cases, extractions seem to be made from cerussite mineral ores ( $\mathrm{PbCO} 3)$. Low amounts of $\mathrm{Pb}$ indicate their comparative purity and can show that Sasanian mineralogy as well as their metallurgy was relatively well developed.

\section{Acknowledgments}

We are thankful to Mr. Saffari who is responsible for the XRF and XRD laboratory of Tarbiat Modares University and Mrs. Baseri who is in charge of the Coins Cabinet in the Iran National Museum.

\section{References}

BACHARACH, J. L., GORDUS, A. A. 1972: The Purity of Sasanian Silver Coins: An Introduction. Journal of the American Oriental Society 92(2), 280-283.

FLAMENT, C., MARCHETTI, P. 2004. Analysis of ancient silver coins. Nuclear instruments and methods in physics research section B: Beam interactions with Materials and Atoms 226, 1-2, 179-184.

FRYE, R. N. 2005: TheSassanians. In: Bowman, A., Camron, A., Garnsey, P.: The Cambridge Ancient history XII. Cambridge University Press, Cambridge, 461-480.

GORDUS, A. A. 1967: Quantitative Non-destructive Neutron Activation analysis of silver in coins. Archaeometry 10(1), 78-86.

GUERRA, M. F. 1995: Elemental analysis of coins and glasses. Application and Isotopes 46(6-7), 583-588.

GUERRA, M. F. 1998: Analysis of Archaeological Metals. The Place of XRF and PIXE in the Determination of Technology and Provenance. $X$-Ray Spectrometry 27(2), 73-80.

GUERRA, M. F, CALLIGARO, T. 2004; Gold traces to trace gold. Journal of Archaeological Science 31, 1199-1208.

GUERRA, M. F. 2004: Fingerprinting ancient gold with proton beams of different energies. Nuclear Instruments and Methods in Physics Research B 226(1-2), 185-198.

GUERRA, M. F, RADTKE, M., REICHE, I, RIESEMEIER, H, STRUB, E. 2008: Analysis of trace elements in gold alloys by SR-XRF at high energy at the BAMline. Nuclear Instruments and Methods in Physics Research B 266, 2,334-2,338.

HAJIVALIEIL, M., MOHAMMADIFAR, Y, GHIYASI, K., JALEH, B, LAMEHI, M, OLIAIY, P. 2008; Application of PIXE to study ancient Iranian silver coins. Nuclear Instruments and Methods in Physics Research B 266, 1578-1582.

HUGHES, M. J, HALL, J. L. 1979: X-ray fluorescence analysis of late 
Roman and Sasanian silver plate. Journal of Archaeological Science 6(4), 321-344.

KANTAReloU, A., AGER, F., EUGENidoU, D., CHAVES, F., ANDREOU, A., KONTOU, E., RERSPALDIZA, M. M. 2011: X-ray Fluorescence analytical criteria to assess the fineness of ancient silver coins: application on Ptolemaic coinage. Spectrochimica Acta part B: Atomic spectroscopy 66/9-10, 681-690.

KATSANOS, A. A., TOURATSOGLOU, J, KALLITHRAKAS-KONTOS, N. 2000: Trace element analysis of Alexander the Greats silver tetradrachms mint in Macedonia. Nuclear Instruments and Methods Research B 171(3), 342-349.

KALLITHRAKAS-KONTOS, N., KATSANOS, A. A., TOURATSOGLOU, J. 2000: Trace Element analysis of Alexander the Greats silver tetradrachms mint in Macedonia. Nuclear instruments and Methods Research B 171 (3), 342-349.

LINK, R., SCHREINER, M., DEMORTIER, G. 2004: The application of photon, electron and proton induced X-ray analysis for the identification and characterization of medieval silver coins. Nuclear Instruments and Methods Research B 226(1-2), 172-178.

LIRITZIS, I., ZACHARIAS, N. 2010: Portable XRF of archaeological artefacts: current research, potentials and limitations. In: Shackley, S. (Ed.): X Ray Flourescence Spectrometry in GeoArchaeology. Natural Sciences in Archaeology Series, Springer North America, 109-142.

MEYERS, P. 2003: Production of silver in Antiquity: ore type identified based upon elemental compositions of ancient silver artifacts. In: Patterns and Process. A Festschrift in Honor of Dr. Edward V. Sayre, 271-288. 
